\title{
Shariah Governance in Islamic Financial Institutions in Nigeria: An Empirical Study
}

\author{
Mohd Sadad Mahmud ${ }^{1}$, Ibraheem Alani AbdulKareem ${ }^{1, *}$, Muqaddam Oyetunji \\ Ali $^{1}$, Isti Fadah ${ }^{2}$, Ah Ali Arifin ${ }^{3}$ \\ ${ }^{1}$ Faculty of Business and Management, Universiti Sultan Zainal Abidin, Terengganu, Malaysia. \\ ${ }^{2}$ Faculty of Economics and Business, University of Jember, Jember, Indonesia. \\ ${ }^{3}$ Faculty of Islamic Economics and Business, UIN Sunan Ampel, Surabaya, Indonesia \\ *Corresponding author. Email: ibraheemalanil@yahoo.com
}

\begin{abstract}
This study examines the elements of Shariah governance in Islamic financial institutions in Nigeria. In this study, a quantitative research method is utilized to gather data via a survey approach using questionnaires. The data were acquired from members of ACE, SAs, academia, religious preachers, banks customers and banks auditor in Nigeria. The outcome of the study demonstrated that the Advisory Committee of Experts, and Board of Directors have a positive significant relationship with Shariah governance of the Islamic financial institutions. Furthermore, this study found Executive Management to have a negative significant relationship with Shariah governance. However, the outcome of the study demonstrated that the Shariah audit has a negative insignificant relationship with Shariah governance. This study shows that Shariah governance of Islamic financial institutions needs to work in coordination with the Board of Directors, Executive Management, and Advisory Council of Experts to achieve the obejective of Islamic finance and Shariah compliance in every product and service. Therefore, the result of the study may assist practitioners and users in recognising the elements that influence Shariah governance as the backbone of Islamic finance in Nigeria. Also, the study contributes to non-interest banks by confirming the elements of the Shariah governance that may impacts the development and growth of non-interest banks in the country.
\end{abstract}

Keywords: Islamic Financial Institutions, Nigeria, Non-Interest Banks, Shariah Governance.

\section{INTRODUCTION}

Islamic finance and banking (IFB) is one of the fast-developing sectors in the global financial system. Islamic banks nowadays are operating in various Muslim and non-Muslim countries. In Nigeria, the first Islamic bank (Muslim Bank of West Africa Limited) was established in 1961. However, the operation of that bank was short-lived in 1962 when the then Minister of Finance ordered the bank closure. After some years, the Central Bank of Nigeria (CBN) in 1992 again granted a license to the Habib Nigerian Bank limited (later Bank PHB PLC and now known as Keystone Bank) to commence non-interest banking service on a "window basis" [1]. Similarly, Lotus Capital Limited was established as a halal fund in the year 2004 and has been operating as an Islamic financing company dealing in Shariahcompliant investment and fund management activities. Moreover, the first full-fledged Islamic microfinance bank called Al-Barakah started operation in 2010 in Lagos State, Nigeria. In addition, in 2012 the first full-fledged Islamic noninterest bank (Jaiz Bank) commenced operation and has been in operation since then till date [2;3].

The operation of IFB in Nigeria is deficient without acknowledging the contribution of the Banks and Other Financial Institutions Act (BOFIA 1991). The CBN is the highest regulatory body assigned with the responsibility of issuing licenses for the operation of all banking services in Nigeria. The pronouncement of the CBN Act 2007 and BOFIA 1991 was indeed a significant improvement in the attempt to confer some measures of autonomy to CBN to effectively carry out its core mandate [3]. The CBN Act of 2007 flagged another period of economic reforms in Nigeria. One of the autonomy is to functions as supervisor and regulator of the Noninterest Banks (NIB) in Nigeria. It is, hence, important to mention that the stipulations of the CBN 
Act 2007 and BOFIA 1991 create a valid basis for the operation of NIB in the country [4;2]. According to [5] Islamic banking (IB) in Nigeria is classified under "specialized bank" acknowledged by the BOFIA 1991. Subsequently, NIB is commonly based on Islamic commercial jurisprudence (ICJ) [6].

According to [7], interest (riba) is prohibited in Islam, unlike the traditional banking system which is based on interest. The modern IB system has been introduced to the market as an alternative to the traditional banking system. The operation of IB must be in accordance with the Shariah principles whereby the charging or collection of interest and other contracts or activities are prohibited by Shariah [8]. In this regard, to guarantee compliance of Shariah, services, products and contracts should be endorsed and supervised by the Financial Regulation Advisory Council of Experts (FRACE) established and regulated by $\mathrm{CBN}$, and the Advisory Committee of Experts (ACE) established and regulated by other financial institutions. These bodies are known as Shariah Advisory Council (SAC) and Shariah Advisory Board (SAB) in other countries such as Malaysia [9; 10]

The customers of IB require compliance with Shariah regulations $[11 ; 12]$. Effective and strong Shariah governance (SG) practice enhance the level of confidence in IB. Without an adequate SG component, the bank operations would face nonShariah complaint risk, reputational risks, and loss of revenues. Diverse regulatory authorities around the world have issued various guidelines and standards to improve SG practices in Islamic financial institutions (IFIs). SG is a unique element to IFIs where the ACEs plays a leading role in guaranteeing IFIs compliance with Shariah principles. Despite being a unique element of IFIs and IBs, recent studies by scholars and World Bank [13] reported that the SG of IFIs is considered to be relatively weak. The weaknesses are attributed to the lack/inadequate inclusion of provisions for the SG in the legislation at the national level. The adequacy of SAC has likewise been questioned and highlighted since it always lacks members with various technical backgrounds [14].

[15] stated that there is a dearth of literature in the supervisory and regulatory framework for Islamic finance, particularly on SG. In addition, [16] affirm that uncertainty of SG and enforceability issues are identified under the Nigerian Islamic finance system. Therefore, SG is important but it is not only to established Shariah-compliant but also to build customers confidence. From Nigeria point of view, the SG framework issued by the CBN is a drive to reinforce the SG framework in IFIs [17]; [18[; [9]. Therefore, the primary objective of this study is to examine the impact of the important elements of the SG such as the Board of Directors, Executive Management, ACE and Shariah Audit on the improvement of SG of IFIs in Nigeria. The study adopted primary data collection.

\section{LITERATURE REVIEW}

\subsection{Shariah Governance}

In 2012, the operation of full-fledged IB was launched in Nigeria 2012 with Jaiz Bank by the approval of the CBN. To strengthen the Shariahcompliant of IB in the country, the $\mathrm{CBN}$ issues regulations to robust the operation [19]. SG is an important and unique element of the IB industry [20] which differentiates IB from the traditional banking system. The SG guarantees the compliance of Shariah in IFIs [14; 21]. The Islamic Financial Service Board (IFSB) (2009) describes SG as " a set of institutional and organizational arrangements through which IFIs ensure that there is effective independent oversight of Shariah compliance over the issuance of relevant Shariah pronouncements/resolutions and its dissemination, as well as an internal and annual Shariah compliance review/audit" [22, P.2].

According to [14], SG is regarded as the hierarchical and deliberate process which would empower the identification of a much larger group of actors aside from the top management to be considered as potential practitioners. Moreover, a robust SG requires the establishment of effective structures, controls and processes to ensure that Shariah principles and requirements are fulfilled in all the operations and transactions of IBs. SG indicates a mechanism to upholding Shariah rules in everything relating to running affairs of Shariah compliant of Islamic finance. It is also viewed as a part and parcel of the corporate governance of IFIs. SG is vital to guarantee effective compliant of Shariah and validity of IFIs transaction [23].

[24] noted that SG is viewed as a unique kind of governance in the architecture of finance. It involves the religious aspect of the general activities of IFIs as compared to the traditional concept of corporate governance. The author further stated that due to the development of Islamic finance around the globe, the Shariah board (SB) require an upgraded governance framework. Especially, efficient SG is important to strengthen the credibility of IFIs. Inability to provide adequate SG would unavoidably lead to serious disturbances in the market which would have critical 
effects for IFIs. A study conducted by [18] concluded that an effective and sound SG will give the general public confidence about Islamic finance in Nigeria.

A SG refers to a mechanism or institutional procedures through which effective supervision, accountability, and obligations of managing IFIs are ensured to be in accordance with Shariah principles and rules. Subsequently, ensuring SG of IFIs and transactions through it is a crucial regulators' responsibility [16]. To execute SG more effectively and appropriately in the IFIs, there are major elements of SG that must play a significant role. These elements are the Board of Directors, Executive Management, Advisory Committee of Experts (ACE), known as Shariah Advisory Council (SAC) in some countries, and Shariah Audit or Shariah review [9]. These elements are highlighted in the subsequence sections.

\subsection{Advisory Council of Experts}

The globally recognized terminology for the Shariah Supervisory Board (SSB) and Shariah Advisory Council (SAC) is FRACE and ACE in Nigeria. SSB is simply known as SB. ACE is frequently considered as the essential player in the SG of IB as stated by [25] that, to monitor the daily operation of IB, the SBs need to certify that Shariah principles and rules have been observed in all IB services and activities. [24] further clarify that ACE is an independent group assigned with the duty of supervising, reviewing, and directing the activities of IFIs to be compliant with Shariah principles. A similar definition was given by IFBS as cited in [9] that "a body comprised of a panel of Shari'ah scholars who provide Shari'ah expertise and acting as special supervisors to the institutions" (P. 304).

Accounting and Auditing Organization for Islamic Financial Institution (AAOIFI) in [26] also describes ACE as "an independent body entrusted with the duty of directing, reviewing, supervising the activities of IFIs for the purpose of Shari'ah compliance and issuing legal rulings pertaining to IB and finance" [27]. [8] posit that SB are experts in Islamic commercial jurisprudence. The authors mentioned that experts in another field can be among the ACE such as experts in economics, law, banking, Islamic economics as the technical members. The main duties of the SB are to supervise the core activities of IFIs and also to guarantee that IFIs services, products, and businesses are compliant with the objective of Shariah. They issue guidelines and fatwas base on Shariah principles. [12] affirm that
ACE members are the significant pillar of the SG. Moreover, an independent, competent and empowered ACE is significant to certify the compliance of Shariah instruments.

[28] asserted that the major requirement for IFIs that offer products and services of IB is the establishment of ACE to advise and to ensure that all services are in line with Islamic principles. [29] is of the view that there is a shortage of Shariah competent in the field of Islamic finance and banking. [17] suggested that this issue of shortage of Shariah talents and manpower can be solved by establishing a research centre to train Shariah scholars in Nigeria. A study by [21] examined the effectiveness of ACE in IB in the Malaysian context, particularly, the issues related to the eligibility of SB members such as consistency, independence, competency, and up to date information and knowledge. [30] investigated the role of the Shariah scholars outside and inside of the Islamic banks' operation such as Shariah consulting firms, SAs and ACE. The study also investigated the functions of ACE. The main find of the study is the absence of standardization of the position of Shariah scholars within the corporate hierarchy in Islamic banks. Based on the above arguments, this study proposed the following hypothesis:

\section{H1: ACE is positively related with SG.}

\subsection{Executive Management}

Executive management (EM) of a financial institution is the top management committee including the highest management staff and executive directors of the bank. This EM review and formulate strategies to implement the board's strategic directions in numerous areas such as external relations, investor relations, customer service, operations, manpower planning, strategic planning, financial and business performance, and organizational competence among others [31]. [8] examined the role of SSB and EM and recommended that the EM of Islamic banks should be guided by SG revelation. Also, [32] emphasized the significance of EM in the process of the legitimacy of SG. The author stated that an organization's achievement particularly on Islamic banks is subjected to the tendency of the organization to implement Islamic principles. SG should depend on the organizational administration based on the ethical code of conduct and the establishment of acceptable resources for business operation. The process and strategies would 
be deficient in case there are not realised and administered absolutely [32].

A study conducted by [33] found that the EM influence IFIs procedure on SG rules in Bangladesh. [34] also affirmed that a sound SG will enhance the Shariah implementation quality by making appropriate combinations and linkage with EM, SSB, and other parts related to the organization. It has also been found by [34] that EM of Islamic banks indirectly influences the functions and practices of the SB, their activities and other decision making. Nevertheless, from either moral or ethical grounds, EM does not have absolute power to control SB activities. Sometimes EM and BOD utilize the SB as a showcase and rubber stamp to achieve their objective and to maximize profit either fully or partially. Hence, the above lead us the propose the following hypothesis.

$\mathrm{H} 2$ : EM is positively related with SG.

\subsection{Board of Directors}

The financial institution's Board of directors (BOD) helps managers and protects shareholders to expands the banks' profitability [35]. It has been found by [20] that BOD utilizes the ACE in achieving its goals. BODs are responsible to carry out the recommendations of $\mathrm{ACE}$ and take care of the management to guarantee the business activities of the organizations are in accordance with the principles of Shariah and satisfy the interest of all stakeholders. Besides, management ought to provide compliance of the Shariah report of all Islamic banks activities to the BOD [36]. In Nigeria, the BOD of IFIs shall appoint members of ACE subject to the approval of the CBN. More so, the appointment shall be for a renewable term of four (4) years subject to a maximum of three (3) terms [37; 38].

Traditional banks contain a single layer governing body with the BOD and executive while Islamic banks have an extra layer known as ACEs that monitors the activities related to Shariah. The role of $\mathrm{ACE}$ is to supervise whether Islamic banks contain prohibited trading [39; 40]. The BOD's control and oversight supervised the business of the corporation. The BOD hand over its powers to the chief executive officer (CEO) to manage the business. The authority is responsible to transmit the power from the CEO to the executive management and senior. The responsibility of BOD is to monitor and supervise the performance of the management [41]. Furthermore, the BOD have the authority to appoint SAC and is supervised by the regulations and rules. Also, BOD will be accountable for any non-Shariah compliance in the IFIs activities [42].

[32] described the BOD as an important element that encourages strong SG in IFIs. The author further examined four pillars of $\mathrm{SG}$ and considered management and BOD as the first pillars of the SG framework. The success of an organization, particularly Islamic banks, is subject to the preparedness of the administration to endorse and essentially enact Islamic principles in the operation of the organization. Equally, [43] emphasized the role of the BOD in guaranteeing the adequate implementation of the SG. [61] examined the significance of SG of the Islamic banks and emphasized similarities between traditional banks and Islamic banks. The authors likewise recommended that SG is a criterion for Islamic banks that could entice potential investors. In addition, the BOD of the Islamic banks shall refer to the FRACE as the authority if there is any conflict [9]. Hence, the following hypothesis is proposed.

H3: BOD is positively related with SG.

\subsection{Shariah Audit or Shariah Review}

Shariah audit (SA) is an independent examination of the financial transaction of IFIs to guarantee adequate Shariah-compliant of Islamic financial products and services [11]. [44] elaborate the main objective of SA as "to ensure that the management of an IFI discharges their responsibilities in relation to the implementation of the Shariah rules and principles as determined by the IFI's Shariah Supervisory Board" (P.378). In addition, [45] defines $\mathrm{SA}$ as "periodical assessment conducted from time to time, to provide an independent assessment and objective assurance designed to add value and improve the degree of compliance in relation to the IFI's business operations, with the main objective of ensuring a sound and effective internal control system for Shariah compliance" [45, p. 23]. Moreover, SA is one of the most important components of Islamic banks and it is different from the traditional banks [20].

A study conducted by [46] found out that the SA function has put value into IFIs in time of Shariahcompliant principles. The authors further assessed the effect of the SA function in time of SG implementation utilizing a case study approach that incorporates interviews about SA. The study concluded that the risk of non-Shariah compliant 
could be alleviated through proper SA. [47] examined the existing SA practices among IFIs in Malaysia utilizing interviews as a method of data collection. The study showed that the current practices of SA in Malaysia are in the initial stage and still need upgrading.

[48] claimed that SA should include a systematic review of the operational aspect of the Islamic banks. This will involve an investigation of the procedures and policies of Islamic banks such as contracts, operational processes, manuals products and so on. SA equally requires inspecting the organizational structure to confirm if it is feasible to undertake compliance of Shariah activity. This will occur if there is available quality of staff with adequate knowledge of Islamic jurisprudent to sustenance the operations of Islamic banks. [49] investigated empirically the gap between "the actual and desired" practice of SA in the Islamic banks in Malaysia. The outcome of the study revealed that there is a gap between "the actual and desired" and it demonstrates that SA functions do not have any considerate impact on Islamic banks in the country, despite its potential as a monitoring instrument for Shariah compliance.

Another study by [50] assessed the significance and independence of SAC members in Islamic cooperatives and IFIs in Malaysia utilizing questionnaires. The results show that $52 \%$ of SA has total independence. The authors' view team members of SA as deficient and lack experience. The respondents opined that SA should enhance their educational level. The outcome of the previous study also shows that the shortage of SA talents is one of the main issues and challenges facing IFIs globally [51; 52]. More so, the scarcity of competent and qualified SA to perform the SA is one of the challenges facing the IFIs in Malaysia [51; 52]. Thus, we proposed the following hypothesis:

$\mathrm{H} 4$ : SA is positively related with $\mathrm{SG}$.

\section{METHODOLOGY}

Islamic finance is one of the fast-growing financial institutions in the global financial system. Therefore, the main objective of this research is to examine the impact of the basic elements of SG such as the BOD, EM, SA, and ACE as independent variables on the improvement of SG of IFIs in Nigeria. The population of the study consist of all the members of ACE, SAs, academia, religious preachers, banks customers and banks auditor in Nigeria. Since there is no record of the total number of the target population, this study uses a nonprobability type of sampling. Also, a convenience sample technique was used for the data collection. According to [53] and [54], this method is suitable to be utilized during the information gathering because of its convenience and relatively low-cost factors.

The researchers collaborate with one of the managers from the ACEs, religious preachers, and the management of the public universities to whom the questionnaire was sent. One of the ACEs and other public officers were chosen to assist distribute the questionnaire to the other members. This is an alternative method for the researchers to collect data face to face with the respondents due to the government movement restriction to prevent the spread of coronavirus. The questionnaire of this study incorporates two sections. Section A respondent's demographic variables such as gender, age, marital status, educational level, designation, and organization working with. Section B incorporates the questionnaire items which utilized to measure four independent variables and dependent variable. The four independent variables incorporate in this research (BODs, EM, ACEs, and SA) are adopted from [8]. 315 questionnaires were returned by the respondent of which 299 were used for analyses. The collected data were entered into SPSS and followed by using PLS-SEM.

\section{DATA ANALYSIS}

\subsection{Descriptive Statistics}

The descriptive statistic based on standard deviation and mean for the studied variables are presented in this section as shown in Table 1 below. Also, Table 2 shows the descriptive statistics of the demography items. Mean is the average value of a given data set which is used to measure the central tendency [55]. In contrast, the standard deviation is the square root of variance which measures the variability in the data set. Generally, the mean of the studies variables is between the range of 4.1338 to 4.3458 .

Table 1. Mean and Standard Deviation

\begin{tabular}{clcr}
\hline s/n & Descriptive & Mean & $\begin{array}{r}\text { Standard } \\
\text { deviation }\end{array}$ \\
\hline 1. & $\begin{array}{l}\text { Advisory council of } \\
\text { experts }\end{array}$ & 4.2592 & 0.59027 \\
2. & Executive management & 4.3458 & 0.56827 \\
3. & $\begin{array}{l}\text { Board of directors } \\
\text { 4. }\end{array}$ & 4.3110 & 0.56462 \\
& Shariah audit or & 4.2562 & 0.51166 \\
5. & Shariah Review & 4.1338 & 0.48805 \\
\hline
\end{tabular}


Table 2. Demographic table

\begin{tabular}{|c|c|c|c|}
\hline Variable & Description & Frequency & $\%$ \\
\hline \multirow{2}{*}{ Gender } & Male & 239 & 79.9 \\
\hline & Female & 60 & 20.1 \\
\hline \multirow[t]{5}{*}{ Age } & 30 and below & 57 & 19.1 \\
\hline & $31-40$ & 81 & 27.1 \\
\hline & $41-50$ & 105 & 35.1 \\
\hline & $51-60$ & 47 & 15.7 \\
\hline & 61 and above & 9 & 3.0 \\
\hline \multirow[t]{2}{*}{ Marital status } & Single & 83 & 27.8 \\
\hline & Married & 216 & 72.2 \\
\hline \multirow[t]{3}{*}{ Education Level } & Primary & 0 & 0 \\
\hline & Secondary & 34 & 11.4 \\
\hline & Tertiary Institution & 265 & 88.6 \\
\hline \multirow[t]{5}{*}{ Designation } & Shariah Advisor Committee member & 111 & 37.1 \\
\hline & Bank’s Customer & 50 & 16.7 \\
\hline & Bank Auditor & 49 & 16.4 \\
\hline & Religious Preacher & 34 & 11.4 \\
\hline & Academic/Teacher & 55 & 18.4 \\
\hline \multirow[t]{7}{*}{ Organization working with } & Full-fledged Islamic financial institution & 99 & 33.1 \\
\hline & Islamic banking branch & 65 & 21.7 \\
\hline & Central Bank & 41 & 13.7 \\
\hline & Islamic window in conventional bank & 29 & 9.7 \\
\hline & Conventional Bank & 14 & 4.7 \\
\hline & Government/Private Employee & 27 & 9 \\
\hline & Businessmen & 24 & 8 \\
\hline
\end{tabular}

The above result shows that there are more male respondents $239(79.9 \%)$ than female respondents $(20.1 \%)$. Also, respondents of age range $41-50$ have the most representation with 105 respondents, followed by the age group $31-40$ years which has 81 representations. The age group 60 and above have the least respondents as it has only 9 representations. In addition, 216 of the respondents are married while only 83 are single. In terms of education level, respondents with tertiary qualifications have 265 representations while only 34 of the respondents hold a secondary certificate. None of the respondents have below the secondary education. In relation to the designation, 111 of the respondents are Shariah Advisor Committee members, while 50 are bank customers, 49 are bank auditors, 34 are religious preachers, and 55 are academicians or teachers. Lastly, the organizations that the respondents' works show that 99 of the respondents works at a fullfledged Islamic financial institution, 65 work at a branch of an Islamic bank, 41 work at the central bank, 29 work at Islamic window in a conventional bank, 14 works at a conventional bank, 27 are government or private employee while 24 are businessmen.

\subsection{Multicollinearity}

According to [56], the issue of multicollinearity can be assessed through VIF (Variance Inflation Factors) and the tolerance value (1/VIF). Moreover,
[56] noted that there is a problem of multicollinearity when the value of VIF is above 5. Hence, as presented in table 3 below, the value of VIF for all independent variables is below the value of 5 , which indicate that there is no problem of multicollinearity in this study.

Table 3. Multicollinearity

\begin{tabular}{lc}
\hline Variables & VIF \\
\hline Advisory council of experts & 2.417 \\
Executive management & 2.453 \\
Board of directors & 1.834 \\
Shariah audit or Shariah & 1.784 \\
Review & \\
\hline
\end{tabular}

\subsection{Measurement model}

The purpose of the measurement model is to ensure the validity and reliability of the model specification. Hence, this study uses factor analysis to determine the authenticity of the model. According to [57], the most important criteria used in evaluating the theoretical framework is the validity and reliability of the framework. Furthermore, [57] recommend that the composite reliability of each variable should be assessed before establishing the construct validity through discriminant validity and convergent validity. To ascertain the convergent validity, it is compulsory to consider the average variance extracted (AVE), composite reliability (CR), Rho_A and the outer loadings of the items [58]. According to [59], AVE and items loadings should 
not be less than 0.50 and 0.70 respectively. However, researchers have proposed that outer loadings that fell below 0.70 should be retained if it contributes to path significance, AVE, and other factors in the model [60]. The result of the measurement model is presented in Figure 1 and Table 4 below.

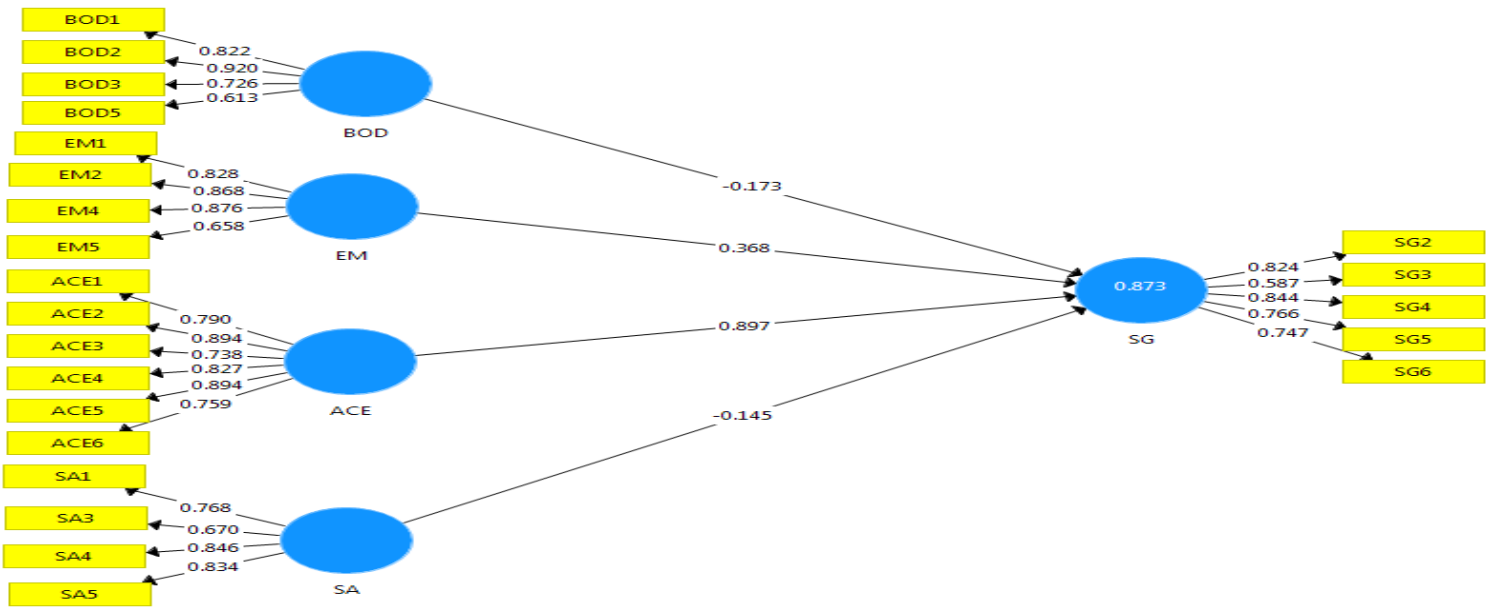

Figure 1 Measurement model

Table 4. Factor Loading Significance

\begin{tabular}{|c|c|}
\hline $\begin{array}{l}\text { Constructs } \\
\text { and items }\end{array}$ & Loadings \\
\hline $\begin{array}{l}\text { Advisory } \\
\text { council of } \\
\text { experts }\end{array}$ & AVE: 0.671; CR: 0.924; Rho_A: 0.904 \\
\hline ACE1 & 0.790 \\
\hline ACE2 & 0.894 \\
\hline ACE3 & 0.738 \\
\hline ACE4 & 0.827 \\
\hline ACE5 & 0.894 \\
\hline ACE6 & 0.759 \\
\hline $\begin{array}{c}\text { Executive } \\
\text { management }\end{array}$ & AVE: 0.659 ; CR: 0.884; Rho_A: 0.849 \\
\hline EM1 & 0.828 \\
\hline EM2 & 0.868 \\
\hline EM4 & 0.876 \\
\hline EM5 & 0.658 \\
\hline $\begin{array}{l}\text { Board of } \\
\text { directors }\end{array}$ & AVE: 0.606; CR: 0.858; Rho_A: 0.794 \\
\hline BOD1 & 0.822 \\
\hline BOD2 & 0.92 \\
\hline BOD3 & 0.726 \\
\hline BOD5 & 0.613 \\
\hline $\begin{array}{l}\text { Shariah audit } \\
\text { or Shariah } \\
\text { Review }\end{array}$ & AVE: 0.612; CR: 0.862; Rho_A: 0.817 \\
\hline SA1 & 0.768 \\
\hline SA2 & 0.670 \\
\hline SA3 & 0.846 \\
\hline SA4 & 0.834 \\
\hline $\begin{array}{c}\text { Shariah } \\
\text { governance }\end{array}$ & AVE: 0.576; CR: 0.870; Rho_A: 0.837 \\
\hline SG2 & 0.824 \\
\hline SG3 & 0.587 \\
\hline SG4 & 0.844 \\
\hline SG5 & 0.766 \\
\hline SG6 & 0.747 \\
\hline
\end{tabular}

Table 5. Discriminant Validity (Fornell and Lacker)

\begin{tabular}{cccccc}
\hline & ACE & BOD & EM & SA & SG \\
\hline ACE & 0.819 & & & & \\
BOD & 0.724 & 0.778 & & & \\
EM & 0.674 & 0.733 & 0.812 & & \\
SA & 0.664 & 0.685 & 0.703 & 0.783 & \\
SG & 0.519 & 0.534 & 0.677 & 0.499 & 0.759 \\
\hline
\end{tabular}

Table 5 shows that this study has established the discriminant validity as it shows the extent to which each construct is different from the other constructs considering the statistical range [56]. Hence, it is concluded that this study has met the discriminant validity assumption since all the diagonal values in the same rows and columns are higher than the offdiagonal values.

\subsection{Structural model}

The researchers are required to establish a structural model to ascertain the significance of the hypothesized relationship. For the structural model to be established a bootstrapping subsample of 5000 is required as this will enable to ascertain the degree of significance loadings, and path coefficients [57].

Having performed the bootstrapping, the result of the structural model that was obtained from PLS is shown in Table 6. Also, figure 1 reveals the determination coefficient (R2) and the path coefficients of each variable. Table 5 reveals that ACE has a positive and significant association with $\mathrm{SG}(\beta=0.895, \mathrm{t}=12.339)$. In addition, $\mathrm{EM}$ was also positive and significantly related with $\mathrm{SG}(\beta=0.374$, 
$\mathrm{t}=8.958)$. Moreover, $\mathrm{BOD}$ was found to have a negative and significant relation with $\mathrm{SG}(\beta=-0.171$, $\mathrm{t}=3.47)$. However, this study documents no relationship between $\mathrm{SA}$ and $\mathrm{SG}(\beta=-0.151, \mathrm{t}=$ 1.834). Thus, this result supports the assumption of hypotheses 1, 2, and 3. However, hypothesis 4 which state a significant relationship between SA and SG is not supported. Table 6 and figure 2 shows the result of the structural model.
Table 6. Result of structural model

\begin{tabular}{llllll}
\hline Hypothesis & Path & $\beta$ & SE & $\begin{array}{l}\text { T. } \\
\text { Value }\end{array}$ & $\begin{array}{l}\text { P- } \\
\text { value }\end{array}$ \\
\hline H1 & $\begin{array}{l}\text { ACE - } \\
\text { SG }\end{array}$ & 0.895 & 0.073 & 12.339 & 0.000 \\
H2 & $\begin{array}{l}\text { EM -> } \\
\text { SG }\end{array}$ & -0.171 & 0.05 & 3.47 & 0.001 \\
H3 & $\begin{array}{l}\text { BOD - } \\
\text { > SG }\end{array}$ & 0.374 & 0.041 & 8.958 & 0.000 \\
H4 & $\begin{array}{l}\text { SA -> } \\
\text { SG }\end{array}$ & -0.151 & 0.079 & 1.834 & 0.067 \\
\hline
\end{tabular}

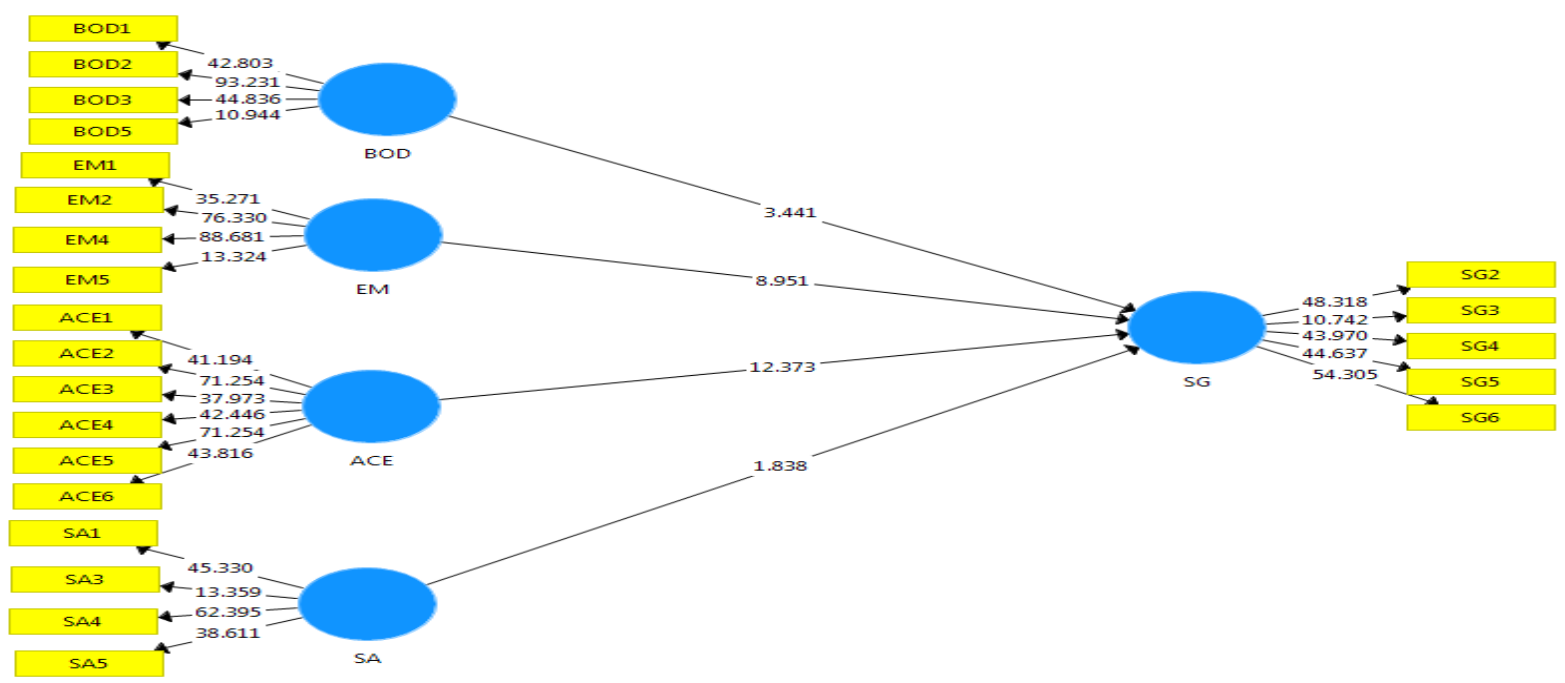

Figure 2 Structural model

\section{DISCUSSION OF FINDINGS}

This research examined the factors that influence SG in an IFIs. Specifically, this study uses the advisory council of experts, board of directors, executive management, and shariah audit as the factors that influence shariah governance. Hence, four direct hypotheses were formulated. The result of the model shows that three of the four hypotheses are significantly related with shariah governance.

The first hypothesis (H1) shows that the ACEs is positive and significantly related with $\mathrm{SG}$. This result is similar to the findings of [12] and [8]. Meaning that the presence of an advisory council of expertise influences the SG of the IFIs in Nigeria.

The second hypothesis (H2) state that EM has a significant association with SG was also supported. This result is consistent with the findings of [33] and [32]. This finding suggests that the presence of effective executive management increases SG in IFIs.

Moreover, the third hypothesis (H3) states that the BODs is significantly associated with SG was also supported. Previous researchers have documented a similar result [42; [9] indicating that an efficient board of directors impact the SG of the IFIs in Nigeria. Lastly, the fourth hypothesis (H4) states that $\mathrm{SA}$ is positive and significantly related with SG. However, the path coefficient result shows no association between SA and SG of the IFIs in Nigeria. Hence, the hypothesis was rejected.

\section{CONCLUSION}

The focus of this study is to examine the factors that influence SG in IFIs in Nigeria. Particularly, this study examines factors such as ACEs, EM, BOD, and $\mathrm{SA}$ on SG in Nigeria. The reason is that the operation of Islamic banking must be in accordance with the Shariah principles where collection of interest is prohibited by Shariah. Hence, SG is charged with the responsibility of monitoring the activities of IFIs. These elements (ACEs, EM, BOD, and SA) are said to influence SG when performing its responsibilities. This study investigates 299 members of ACEs, SAs, academia, religious preachers, banks customers and banks auditor in Nigeria. Data we collected through the distribution of online questionnaires and analysed using PLS-SEM software. Moreover, SG is the 
dependent variable while ACEs, EM, BODs, and SA are the independent variables.

The outcome of the analysis shows that ACEs and SG are positive and significantly related (Table 6 and figure 2). This result is consistent with our hypothesis. Hence, we conclude that ACEs influence SG. Also, the result shows that the BOD significantly and positively relates with SG (Table 6 and figure 2). This result is consistent with our hypothesis. The result shows that BODs plays an important role in the SG of IFIs. Moreover, the study findings show that EM has a negative and significant relationship with SG which contradicts the proposed hypothesis (Table 6 and figure 2). Therefore, it can be concluded that SG and EM of IFIs are negatively related. Lastly, the result of the analysis shows that SA is negative and have no significant association with $\mathrm{SG}$. This result conflicts with the hypothesis we proposed. Hence, we can conclude that SA does not influence SG of IFIs.

\section{IMPLICATIONS AND LIMITATIONS}

As far as the findings on SG is concerned, the implication of this study shows that shariah governance of IFIs needs to work in coordination with the BOD, EM, and ACEs. Moreover, this research may help practitioners to determine the important factors that may influence the SG of Islamic banks and other IFIs. Besides, this research can be a source of information and knowledge for stakeholders, policymakers, and regulators (especially the $\mathrm{CBN}$ ) on the factors that influence shariah governance in Nigerian IFIs. In addition to the implications, this study has some limitations. Firstly, this study focuses on only four factors of SG. There are other factors such as expertise and independence of BOD, and shariah committee chair that may interest future researchers. Secondly, due to the difficulties in data accessibility, this study focuses on the IFIs in Nigeria. Future studies may extend this research and compare the result in Nigeria environment with other Africa countries. Lastly, future studies may extend the sample size for the generalization of results.

\section{REFERENCES}

[1] M. B. Alkali, and A. H. Buang, "Legal Aspects of Islamic Banking and Finance in Nigeria," Jurnal Syariah., vol. 25, no. 2, pp. 311-362, 2017.

[2] A. Kareem, M. S. Mahmud, and A. AbdulGaniyy, "Thematic Review of Sukuk Ijarah Issued in Nigeria: An Opportunity for Economic
Development," Jurnal Iqtisaduna., vol. 1, no. 1, pp. 61-80, 2020.

[3] A. M. O. I. E. Mubarak, Z. Mustapha, A. M. T. Bin Mohamed, and G. Ibrahim, "Laws of Islamic Banking in Nigeria: Critical Review and Best Practice Proposal," International Journal of Academic Research in Business and Social Sciences., vol. 10, no. 3, pp. 29-42, 2020.

[4] A. M. Hamman, "The Role of Advisory Committee of Experts and Product Development in Nigerian Islamic Banks," 4th International Conference on Accounting, Business and Economics, Primula Beach Hotel, Kuala Terengganu, Malaysia., pp 22-46, 2016.

[5] L. S. Sanusi, Islamic Finance in Nigeria: Issues and Challenges. UK: A Lecture delivered at Markfield Institute of Higher Education, 2011.

[6] H. Sa'id, "Exploring the development of Islamic banking in Nigeria using an actor-network theory perspective," Journal of Islamic Accounting and Business Research., pp. 10831099, 2020.

[7] U. Suharto, "Riba and interest in Islamic finance: semantic and terminological issue," International Journal of Islamic and Middle Eastern Finance and Management., vol. 11, no. 1, pp. 131-138, 2018. DOI: https://org/10.1108/IMEFM-08-2016-0109

[8] , M. A. Shahzad, A. Khan, M. T. Mansoori, and A. Ehsan, "Sharī 'ah Governance in Islamic Banking Institutions in Pakistan: An Empirical Investigation," Journal of Islamic Business and Management., vol. 10, pp. 28-42, 2020.

[9] A. I. Abikan, and I. B. Ahmad, "Shariah Governance of Islamic Financial Institutions (IFIS): An Analysis of the Central Bank of Nigeria (CBN) Regulatory Guidelines," KIU Journal of Social Sciences., vol. 3, no. 1, pp. 303-316, 2017.

[10] Z. Mustapha, S. Kunhibava, and A. Muneeza, "Court referral and Nigeria's financial regulation advisory council of experts (FRACE)," ISRA International Journal of Islamic Finance., vol. 11, no. 2, pp. 206-225, DOI: 10.1108/IJIF-11-2018-0126, 2019.

[11] M. A. Shahzad, S. K. Saeed, and A. Ehsan, "Shar1'ah audit and supervision in Shar ${ }^{-}$'ah governance framework: Exploratory study of Islamic banks in Pakistan," Business \& 
Economic Review., vol. 9, no. 1, pp. 103-118, 2017. Doi: org/10.22547/BER/9.1.6

[12] M. Ayub, M. A. Shahzad, and H. Rehman, "Enhancing the competence and effectiveness of Shar ${ }^{-}{ }^{\text {' }}$ ah advisory boards: Case of Islamic banking institutions in Pakistan," Journal of Islamic Business and Management., vol. 9, no. 1, pp. 45-66, 2019. DOI: Doi.Org/10.26501/Jibm/2019.0901-004

[13] World Bank. World Bank Corporate governance practices in Islamic banks. Bahrain, 2017.

[14] D. Fatmawati, N. M. Ariffin, N. H. Z. Abidin, and A. Z. Osman, "Shariah governance in Islamic banks: practices, practitioners and praxis," Global Finance Journal., pp. 100555, 2020.

[15] V. Sapovadia, "Jaiz: the birth of non-interest banking in Nigeria. in Redford, D.T. (Ed.), Developing Africa's Financial Services-The Importance of High-Impact Entrepreneurship," Emerald Publishing Limited, Bingley., pp 199246, 2017. DOI: 10.1108/978-1-78714-186520171010 .

[16] Z. Mustapha, S. B. Kunhibava, and A, Muneeza, "Legal and Sharī'ah non-compliance risks in Nigerian Islamic finance industry: a review of the literature," International Journal of Law and Management., vol. 63, no.2, pp. 275-299, 2020. DOI: 10.1108/IJLMA-03-2020-0075

[17] I. M. Ahmad, "Operational Challenges in Shariah Governance of Islamic Financial Institutions (IFIs) in Nigeria: Issues and Solutions," Journal of Islamic Economics, Banking and Finance., vol. 12, no. 3, pp. 216235, 2016

[18] H. Ijaiya, A Review of Literature on the Challenges of Shariah Governance in Islamic Banking in Nigeria. Journal of Shariah Law Research., vol. 6, no. 1, pp. 1-10, 2021.

[19] T. Muhammad, S. A. Dauda, and D. Mamman, "The contemporary Islamic banking system (Jaiz bank) in tackling financial exclusion in Nigeria," International Journal of Islamic economics and finance studies., vol. 4, no. 1, pp. 24-40, 2018.

[20] M. K. Alam, S. A. Rahman, H. Mustafa, S. M. Shah, and M. S. Hossain, "Shariah Governance Framework of Islamic Banks in Bangladesh: Practices, Problems and Recommendations,"
Asian Economic and Financial Review, vol. 9, no. 1, pp. 118-132, 2019. DOI: 10.18488/journal.aefr.2019.91.118.132

[21] S. Mohamad, Z. S. Muhamad and M. Shah, Shariah governance: effectiveness of shariah committees in Islamic banks in Malaysia. Available at SSRN 2555373, 2015.

[22] IFSB, Islamic Financial Services Board. [Internet], Guiding Principles on Shari'ah Governance systems for institutions offering. Kuala Lumpur, 2009. Available from www.ifsb.org

[23] R. I. Adebayo, "A study of the legal and regulatory issues of non-interest banking system in Nigeria," Journal of Islamic Banking and Finance., vol. 28, no. 1, pp. 44-58, 2011.

[24] B. H. Malkawi, "Shari'ah Board in the Governance Structure of Islamic Financial Institutions," The American Journal of Comparative Law., vol. 61, no. 3, pp. 539-578, 2013.

[25] A. M. Ayedh, and A. Echchabi, "Shari'ah supervision in the Yemeni Islamic banks: a qualitative survey," Qualitative Research in Financial Markets., vol. 7, no. 2, pp. 159-172, 2015. Doi.org/10.1108/QRFM-06-2014-0017

[26] A. Muneeza, "Shari'ah Governance Applicable to Islamic Banks in Malaysia: Effect of Islamic Financial Services Act 2013. The Developing Role of Islamic Banking and Finance: From Local to Global Perspectives," (Contemporary Studies in Economic \& Financial Analysis, Vol.95) Emerald Group Publishing Ltd, Bingley., pp. 31-44, 2014. DOI: .org/10.1108/S1569-3759(2014)0000095010

[27] AAOIFI, Governance standard for IFIs, No. 1, Sharia Supervisory Board (SSB): Appointment, Composition \& Report. Bahrain: AAOIFI, 2005.

[28] N. A. Abdullahi, "Islamic banking in Nigeria: Issues and prospects," Journal of Emerging Economies and Islamic Research., vol. 4, no. 2, pp. 34-50, 2016.

[29] D. H. G. Rammal, "Challenges of Sharı 'ah supervision in Islamic financial institutions," Islamic Finance News., vol. 668, pp. 1-7, 2015.

[30] M. A. Shahzad, H. Rehman, S. K. Saeed, and A. Ehsan, "Islamic finance education and curricula of Deeni Madaris (Religious Seminaries): An 
exploratory study," Islamic Banking and Finance Review (IBFR)., vol. 6, pp. 60-77, 2019.

[31] S. Héroux, and A. Fortin, "Exploring the influence of executive management diversity on IT governance," JISTEM-Journal of Information Systems \& Technology Management., vol. 14, pp. 401-429, 2017.

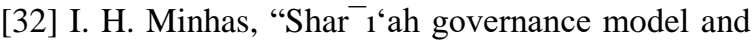
its four basic pillars," Islamic Finance News., Vol. 9, no. 15, pp. 1-3, 2012.

[33] M. K. Alam, A. U. F. Ahmad, and A. Muneeza, "External Sharī'ah audit and review committee vis-a-vis Sharī'ah compliance quality and accountability: case of Islamic banks in Bangladesh," Journal of Public Affairs., 2020. DOI: 10.1002/pa.2364.

[34] M. K. Alam, M. S. Miah, M. N. Siddiquii, and M. I. Hossain, "The influences of board of directors and management in Shariah governance guidelines of the Islamic banks in Bangladesh," Journal of Islamic Accounting and Business Research., vol. 11, no. 9, pp. 16331647, 2020.Doi: org/10.1108/JIABR-08-20190155

[35] M. C. Vu, T. T. Phan, and N. T. Le, "Relationship between board ownership structure and firm financial performance in transitional economy: the case of Vietnam," Research in International Business and Finance, vol. 45, pp. 512-528, 2018. DOI: 10.1016/j.ribaf.2017.09.002.

[36] BNM, Islamic financial service act 2013 (IFSA 2013). Kuala Lumpur: Bank Negara Malaysia, 2013.

[37] S. Héroux, and A. Fortin, "Exploring the influence of executive management diversity on IT governance," JISTEM-Journal of Information Systems \& Technology Management., vol. 14, pp. 401-429, 2017.

[38] I. M. Idris, and N. M. Gatawa, "Challenges of Islamic Banking in Nigeria; Legal and Regulatory Perspectives," Journal of Islamic Banking and Finance., vol. 35, no. 2, pp. 54-67, 2018.

[39] M. R. Karim, and S. A. Shetu, "Level of Shariah Compliance in the Operation of Islamic Banks in Bangladesh: An Empirical Study," International Journal of Islamic Economics and
Finance Studies., vol. 6, no. 3, pp. 293-317, 2020.

[40] S. Mollah, and M. Zaman, "Shari'ah supervision, corporate governance and performance: conventional vs. Islamic banks," Journal of Banking and Finance., vol. 58, pp. 418-435, 2015. DOI: 10.1016/j.jbankfin 2015.04.030

[41] S. K. Saeed, and U. Faiz, Corporate governance in Pakistan (1st ed.). Higher Education Commission, Islamabad, Pakistan, 2018.

[42] M. K. Hassan, M.H. Ullah and R. Khanam, Case studies of Shariah governance practices in Bangladesh Conference Paper, 2017. Available from http://research.usc.edu.au/vital/access/manager/ Repository/usc:25050.

[43] M. K. Alam, F. T. Islam, and M. K. Runy, "Why does Shariah governance framework important for Islamic banks?" Asian Journal of Economics and Banking., vol. 5, no. 2, pp. 158172, 2021. DOI 10.1108/AJEB-02-2021-0018

[44] N. F. Bahari, and N. A. Baharudin, "Shariah Governance Framework: The Roles of Shariah Review and Shariah Auditing," In Proceeding of the 3rd International Conference on Management \& Muamalah., pp. 375-382, 2016.

[45] BNM. Shariah Governance Framework for Islamic Financial Institution (SGF) [Internet], 2011. Available at http://www.bnm.gov.my

[46] Z. Shafii, A. Z. Abidin, S. Salleh, K. Jusoff, and N. Kasim, "Post implementation of shariah governance framework: The impact ofshariah audit function towards the role of shariah committee," Middle-East Journal of Scientific Research., vol. 13, pp. 7-11, 2013. Doi.org/10.5829/idosi.mejsr.2013.13.1874

[47] Y. Yahya, and N. Mahzan, "The role of internal auditing in ensuring governance in Islamic Financial Institutions (IFIs)," Paper presented at the 3rd International Conference on Business and Economic Research, Bandung, Indonesia, 2012.

[48] M. I. H. Kamaruddin, and M. M. Hanefah, "Enhancing Shariah audit practices in Islamic financial institutions in Malaysia," Journal of Modern Accounting \& Auditing., vol. 13, no. 11, pp. 457-470, 2017. 
[49] N. B. Kasim, "Shariah Auditing in Islamic financial institutions: Exploring the gap between the "desired" and the "actual," Global economy and finance journal., vol. 2, no. 2, pp. 127-137, 2009.

[50] M. R. Ahmad, and A. H. Al-Aidaros, "The need of independent Shariah members in Islamic cooperative banks: An empirical study of professional accountants in Malaysia," International Review of Management and Business Research., vol. 4, no. 1), pp. 110-120, 2015.

[51] N. A. M. Ali, Z. M. Mohamed, S. Shahimi, and Z. Shafii, "Knowledge for Shari'ah auditors' competency in Islamic financial institutions," International Journal of Trade, Economics and Finance, vol. 7, no. 4, pp. 113-120, 2016.

[52] N. A. M. Ali, S. Shahimi, and Z. Shafii, "Knowledge, Skills and Characteristics Requirements for Shari'ah Auditors," Asian Journal of Accounting and Governance., vol. 9, pp. 171-185, 2018.

[53] K. B. Lim, S. F. Yeo, and J. C. Wong, "Factors Affecting Purchasing Intention by Using Mobile Shopping Applications in Malaysia," International Journal of Business and Society., vol. 21, no. 3, pp. 1058-1067, 2020.

[54] M. P. Battaglia, "Nonprobability sampling," Encyclopedia of survey research methods., vol. 1, pp. 523 - 526, 2008.

[55] U. Sekaran, and R. Bougie, Research methods for business: A skill-building approach. 6th Edn., West Sussex, UK: John Wiley \& Sons Limited, 2013.

[56] J. F. Hair, G. T. M. Hult, C. M. Ringle, and M. Sarstedt, A Primer on Partial Least Squares
Structural Equation Modeling (PLS-SEM). Thousand Oaks: Sage, 2013.

[57] J. F. Hair, G. T. M. Hult, C. M. Ringle, M. Sarstedt, and K. O. Thiele, "Mirror, mirror on the wall: a comparative evaluation of compositebased structural equation modeling methods," Journal of the academy of marketing science, vol. 45, no.5, pp. 616-632, 2017.

[58] M. Salimon, S. Mokthar, M. Yusr, R. Yusoff, O. Kareem, and J. Bamgbade, "Do risk and fun matter in the adoption of mobile commerce in Nigeria? A PLS-SEM approach," Management Science Letters., vol. 8, no. 6, pp. 507-518, 2018.

[59] J. F. Hair, G. T. M. Hult, C. M. Ringle, and M. Sarstedt, A Primer on Partial Least Squares Structural Equation Modeling. Thousand Oaks: Sage, 2014.

[60] M. G. Salimon, R. Z. B. Yusoff, and S. S. Mohd Mokhtar, "The mediating role of hedonic motivation on the relationship between adoption of e-banking and its determinants," International Journal of Bank Marketing., vol. 35, no. 4, pp. 558-582, 2017. DOI: org/10.1108/IJBM-052016-0060

[61] M. A. Rahim, M. S. S. P. M. Shith, and M. R. Osman, Attributes of Sound Shariah Corporate Governance Criteria from Investor Perspective. In 3rd ICBER 2012 Proceeding, 1557-1564, 2012 